\title{
IN-CLOUD AND BELOW-CLOUD SCAVENGING ANALYSIS OF SULFATE IN THE METROPOLITAN AREA OF SÃO PAULO, BRAZIL
}

\author{
F. L. T. GONÇALVES ${ }^{1}$, W. N. MORINOBU, M. F. ANDRADE ${ }^{2} \&$ A. FORNARO² \\ ${ }^{1,2}$ University of São Paulo (IAG-USP), Department of Atmospheric Sciences. \\ Rua do Matão, 1226, 05508-900, São Paulo, Brazil \\ ${ }^{1}$ Corresponding author: e-mail fgoncalv@model.iag.usp.br
}

Received July 2005 - Accepted November 2005

\begin{abstract}
The Metropolitan Area of São Paulo (MASP) is one of the largest urban centers in the world. The significant atmospheric concentrations of ozone, inhalable particles and other pollutants in the MASP raise serious air-quality concerns. In this study, we consider gases, particulate matter (PM) and cloud processes, with a focus on sulfate chemistry. The Regional Atmospheric Modeling System mesoscale numerical model was used in conjunction with detailed scavenging models to compare varying PM mass spectra and size distributions. Field data were collected during the July 1989-May 1990 and February-October 2000 campaigns. Adjusted-urban and rural spectra seem to fit better with observed results which improved the scavenging numerical modeling. Correlations between modeled and observed concentrations were better when the model included rural and adjusted-urban spectra, suggesting locally dominant below-cloud scavenging. Spatial variability analysis and numerical modeling also revealed that the varying sulfate rainwater concentrations indicate below-cloud removal process dominance.
\end{abstract}

Keywords: air pollution, sulfur compounds, numerical modeling, scavenging processes, rainwater chemistry.

RESUMO: ANÁLISE DOS PROCESSOS DE REMOÇ̃̃O DE SULFATO DENTRO E ABAIXO DA NUVEM NA REGIÃO METROPOLITANA DE SÃO PAULO, BRASIL .

A região metropolitana da cidade de São Paulo (RMSP) é uma das maiores aglomerados urbanos do mundo. Significativas concentrações atmosféricas de ozônio, partículas inaláveis e outros poluentes na RMSP aumentam seriamente a qualidade do ar. Neste estudo, nos consideramos os gases, material particulado (PM) e processos formadores de nuvens com foco na química do sulfato. O modelo numérico de mesoscala RAMS (Regional Atmospheric Modeling System) foi usado, em conjunto a um modelo detalhado de remoção, para comparar diferentes espectros do PM e distribuições de tamanho. Dados observados foram coletados durante os meses de Julho de 1989 a maio de 1990 e entre fevereiro e outubro de 2000. Espectros urbano-ajustado e rural parecem ter melhor ajuste aos dados observados com conseqüente avanço na modelagem numérica dos processos de remoção. Correlações entre concentrações modelados e observados foram melhoradas quando o espectro era o rural e o urbano-ajustado, sugerindo uma dominância local e a remoção abaixo da nuvem. Análises da modelagem numérica igualmente mostraram que as variações nas concentrações de sulfato em água de chuva indicam uma dominância dos processos abaixo da nuvem.

Palavras-chave: poluição do ar, sulfato, modelagem numérica, processos de remoção, química de água de chuva. 


\section{INTRODUCTION}

Most current knowledge on acid deposition was developed in the 1950s and 1960s, during which extensive studies by both American and European researchers from various scientific fields demonstrated that acid rain is the end-result of complex chemical and physical interactions of pollutants in the atmosphere (Cowling, 1982). In the atmosphere, sulfur and nitrogen compounds can undergo oxidation in the gas and liquid phases, forming $\mathrm{NO}_{3}{ }^{-}$and $\mathrm{SO}_{4}{ }^{2-}$. These ionic pollutants are typically anthropogenic (from industrial and transportation sources) and are considered to play an important role in the formation of acid rain (Minoura and Iwasaka, 1996). More recently, various studies analyzing the chemical composition of rainwater have been conducted worldwide. Most of these studies have evaluated sulfur compounds, nitrogen compounds and the $\mathrm{pH}$ in bulk precipitation (Cowling, 1982).

Within the same rainfall event, chemical species concentrations can present marked temporal variations. Therefore, sequential sampling during a precipitation event is essential to the evaluation of scavenging processes. Precipitation chemistry is especially useful in the development and evaluation of acidic deposition models, which are designed to simulate and predict the removal process. Among studies evaluating the chemical composition of rainwater as well as scavenging efficiencies, more have been based on the sampling of integrated events (monthly, weekly, daily or per-event) than on the sequential sampling of precipitation (Baez et al., 1992, Poissant and Beron, 1992, Lim et al., 1991, Durana et al., 1992). Various factors control the scavenging efficiency of wet deposition and, consequently, rainwater concentrations. These factors include the type of cloud, the type of precipitation, the air mass trajectory and the solubility of gaseous species, as well as the nature, size and shape of hydrometeors involved in in-cloud and below-cloud scavenging processes.

In recent years, models of in-cloud and below-cloud scavenging processes for air pollutants have been evaluated by some authors who have shown the relevance of inter-compartment transfer from the atmosphere to the hydrosphere. Numerical modeling studies have also been conducted simulating reservoir transfer in many regions around the world, especially in the most heavily polluted areas. However, very few studies have been carried out in tropical areas. The importance of these regions is based on the faster hydrological cycle where the total amount of rainfall is usually quite high.

Cautenet and Lefeivre (1994) and Gonçalves et al. (2003) used numerical modeling to evaluate gas and aerosol scavenging processes in tropical areas. The authors evaluated modeled and observed concentrations of $\mathrm{SO}_{2}, \mathrm{SO}_{4}{ }^{2-}$ and $\mathrm{NH}_{4}{ }^{+}$ in convective rainfall within the African and Amazonian equatorial forests, respectively. Both studies examined the relationship between liquid water and trace element content in convective precipitation. The results compared favorably with the evaluation of the observed data set collected during the ABLE 2B (Amazonian forest) and DECAFE (African forest) experiments. Gonçalves et al. (2003) performed the sampling campaign in the state of Amapá, situated in the northern part of Brazilian Amazonia. The authors determined that the efficiency of aerosol scavenging decreased in proportion to increases in rain intensity and that the vertical profile of atmospheric trace elements had a strong impact on ground-level concentrations of those elements in rainwater. The inclusion of in-cloud data was instrumental in the improved modeling of scavenging processes seen in that study. The authors employed the Regional Atmospheric Modeling System (RAMS) mesoscale atmospheric model, which addresses the spatial and temporal evolution of cloud microphysics within rainfall systems. This model is particularly useful in the analysis of cloud liquid water content, as well as the cloud droplet spectrum and vertical dimensions thereof.

On the other hand, the metropolitan area of São Paulo (MASP) is also in a tropical area, at Southeastern Brazil and faces serious air-quality problems. Through an array of numerous government-funded automatic air-quality monitoring stations, key air pollutants in the area have been measured since 1973 and continuously evaluated since 1981 (CETESB, 2003). The main source of air pollutants in São Paulo is mobile emissions from both the light- and heavy-duty fleet. More than $80 \%$ of nitrogen oxide, carbon monoxide and non-methane hydrocarbon emissions are generated from the burning of fuel used in internal-combustion engines. These fuels include gasohol (22\% ethanol), pure ethanol and diesel. In addition, a significant portion ( $45 \%$ ) of sulfur dioxide emissions is attributable to industrial sources. Within the MASP, 2,000 companies (a small fraction of the total) are responsible for more than $90 \%$ of industrial emissions. Over the past several years, the levels of primary air pollutants have decreased but events with high levels of $\mathrm{NO}_{2}, \mathrm{CO}$, particulate material and ozone still take place. Atmospheric ozone concentrations in the region have reached levels of more than five times that considered protective of public health by the World Health Organization. In the wintertime particulate matter particles levels routinely exceed the $150 \mu \mathrm{g} / \mathrm{m}^{3} 24 \mathrm{~h}$ (CETESB, 2003).

Obviously, air pollution in the MASP is quite broad in scope and is a serious public health problem. Nevertheless, there is no regular program of wet deposition evaluation and data on rainwater composition are scarce and sampling campaigns are sporadic (Forti et al., 1990, Fornaro et al., 1993, Paiva et al., 1997). Many studies have been conducted based on wet-only precipitation between November 1988 and June 1990 (Fornaro et al., 1993, Fornaro, 1991). These studies analyzed only $\mathrm{pH}$, conductivity and anions. The authors reported a 
volume-weighted mean $\mathrm{pH}$ of 4.6 for rainwater. This is similar to the $\mathrm{pH}$ of 4.5 recorded in another study carried out from September 1993 to May 1994 (Paiva et al., 1997).

According to the monitoring air quality data (CETESB 2003), atmospheric sulfur dioxide gas decreased, from $60 \mu \mathrm{g} \mathrm{m}^{-3}$ (in 1990) to $20 \mu \mathrm{g} \mathrm{m}^{-3}$ (in 2000) in MASP area. This drop can be attributed to enhanced control over sulfur emissions, owing to the enforcement of two governmental regulations: mandatory low sulfur content in diesel and gasohol, and controlled percentages of sulfur dioxide and sulfate particulate in industrial emissions. As a consequence, sulfate in rainwater has also decreased, from $24.8 \mu \mathrm{mol} \mathrm{L}^{-1}$ (in 1989, Fornaro et al. 1993) to $9.5 \mu \mathrm{mol} \mathrm{L}^{-1}$ (in 2000). Therefore, enforcement of governmental regulations has proven effective during the last decade.

From 1990 to 1996, several observational field studies were conducted in order to determine the extent of the damage to the Serra do Mar rainforest, nearby MASP (Klockow et al., 1996). Based on data, obtained during a March 1992 campaign from this study and conducted in the Cubatão region (a highly industrialized area near the MASP), Gonçalves et al. (2000 and 2002), presented two numerical modeling studies of cloud processes: with RAMS (Regional Atmospheric Mesoscale Modeling) and a model called B.v.2. The first (in 2000) focused on below-cloud scavenging, whereas the second (in 2002) analyzed in-cloud scavenging where this last model (B.v.2) was developed. The results showed that below-cloud scavenging dominated the scenario in the rain events studied. Because Cubatão is located at the base of a mountain (in the Serra do Mar range) and is surrounded by tropical rainforest, conditions are extremely unfavorable for the dispersion of atmospheric pollutants. As a result, the soil and vegetation have suffered the impact of the pollution, mainly due to the air-water transport. The high annual rainfall rates, which can reach 4,500 $\mathrm{mm}$, contribute to this effect. The results of the Gonçalves et al. (2002) study were quite similar to those of the previously mentioned Gonçalves et al. (2003) Amapá study in that RAMS in-cloud scavenging simulations proved quite useful. Therefore, RAMS-based numerical modeling has demonstrated its value in the investigation of scavenging processes, contributing to the understanding of wet deposition. It is important to note that atmospheric wet deposition is quite relevant to inter-compartment transfer, which has significant consequences for local, as well as global, modeling studies.

The main goal of the present paper is a preliminary investigation of sulfur transfer from the atmosphere to the hydrosphere in the MASP region, with a focus on whether the local or remote effect, through the RAMS numerical modeling with different input spectra. Therefore, the significance of this paper should be on the overall improvement knowledge about the sulfur transferences at the studied region as well as the scavenging numerical modeling.

\section{DATA AND METHODS}

The data were collected at experimental sites (sec. 2.1), analyzed through rain sampling (sec. 2.2), numerical modeling (sec. 2.3) using the rain sampling and the comparison between both (sec. 2.4).

\subsection{Experimental Sites}

The experimental sites were two stations, one in the "Parque Estadual das Fontes do Ipiranga (PEFI)" and the other on the University of São Paulo campus (Cidade Universitária, USP), both within the MASP and both measuring air humidity, temperature, wind direction, and others. The PEFI station is situated at $23.39^{\circ} \mathrm{S}$ and $46.37^{\circ} \mathrm{W}$ at an altitude of $800 \mathrm{~m}$, southeast of the city center. The campus is situated at $23.34^{\circ} \mathrm{S}$ and $46.44^{\circ} \mathrm{W}$, near the city center, at an altitude of $740 \mathrm{~m}$ (Figure 1). The sites are approximately $15 \mathrm{~km}$ apart. There were two main campaigns, July 1989 (only at USP) and July 2000 (at USP and PEFI), which will be compared herein.

It is important to note that MASP area has a subtropical climate with rainfall $1400 \mathrm{~mm}$ per year, mainly from December to March (summer period). In the wintertime the weather is characterized by dry conditions, thermal inversions and events of high air pollutants concentrations.

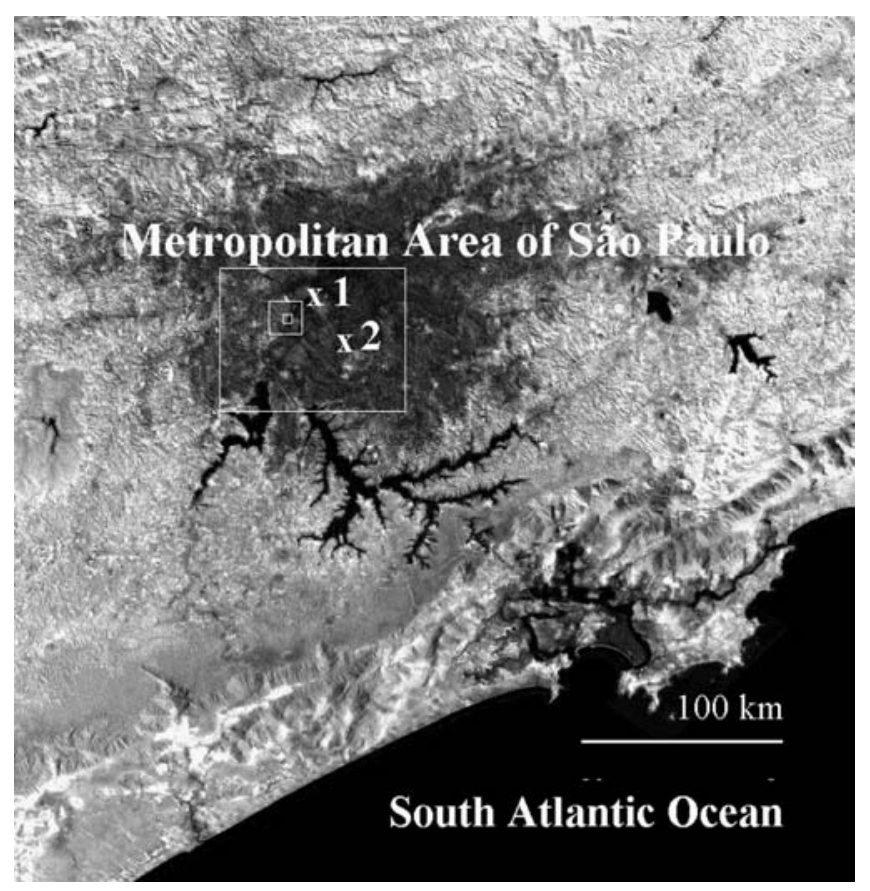

Figure 1 - Localization of the studying area (1 is USP and 2 is PEFI) and approximately the size of the nested grids $(1 \mathrm{~km}, 4 \mathrm{~km}$, and $20 \mathrm{~km}$ ). 


\subsection{Rain and aerosol sampling: observed and input data}

Specific collectors, placed in both locations, were used to gather rainwater samples (wet-only), that were then analyzed for sulfate. In the 1989 campaign, a DIONEX 4000i chromatographer with an AS5 (Dionex) column was used for this purpose. The eluent was a mixture of $3.1 \mathrm{mmol} \mathrm{L}^{-1}$ of $\mathrm{Na}_{2} \mathrm{CO}_{3}$ and $3.9 \mathrm{mmol} \mathrm{L}^{-1}$ of $\mathrm{NaHCO}_{3}$, flowing at a rate of $1 \mathrm{~mL} \mathrm{~min}^{-1}$. A suppresser column (AMMS, Dionex) and a regenerant solution of $20 \mathrm{mmol} \mathrm{L}^{-1} \mathrm{H}_{2} \mathrm{SO}_{4}$ were also used. The samples were filtered with Millex 0.45- $\mu \mathrm{m}$ Millipore filters (Fornaro, 1991).

In the 2000 campaign, rainwater sulfate was determined by capillary zone electrophoresis using contact-less conductivity detection as described by Rocha et al. (2003), as well as by Fornaro and Gutz (2003). In the present study, a $75 \mu \mathrm{m}$ internal diameter fused silica capillary, $60 \mathrm{~cm}$ in length $(50 \mathrm{~cm}$ before the detector), was employed. The injection was performed hydrostatically by elevating the standard solution or sample by $10 \mathrm{~cm}$ for $30 \mathrm{~s}$, the detector was operated at $600 \mathrm{kHz}$, and the separation potential was $-15 \mathrm{kV}$. Prior to each session, the capillary was treated with $0.2 \mathrm{~mol} \mathrm{~L}^{-1} \mathrm{NaOH}$ for $30 \mathrm{~min}$ and subsequently washed, first with deionized water and then with the buffer solution for $30 \mathrm{~min}$. For anion separation, a $\mathrm{pH} 6.2$ buffer, consisting of $20 \mathrm{mmol} \mathrm{L}^{-1}$ of 2-[morphine] ethanesulfonic acid and $20 \mathrm{mmol} \mathrm{L}^{-1}$ of histidine, was used in combination with a solution of $0.2 \mathrm{mmol} \mathrm{L}^{-1}$ of cetylmethylammonium bromide (CTAB) acting as an electroosmotic flow modifier.

In the winter (August) of 1999, aerosol collection was performed on the University of São Paulo campus $\left(23.34^{\circ} \mathrm{S}\right.$, $\left.46.44^{\circ} \mathrm{W}\right)$, which is situated in the NW periphery of the city. Winter samplings were performed from August 3-13 using a stacked filter unit and a micro-orifice uniform deposit impactor (MOUDI). Aerosol spectra were constructed from the data measured by the MOUDI, which has ten different stages. The nominal 50\% cutoff point (D50) for each stage is: 0.1 (after-filter), 0.18, 0.32, 0.56, 1.0, 1.8, 3.2, 5.6, $10 \mu \mathrm{m}$ and $18.0 \mu \mathrm{m}$ (inlet to cut the particles). The MOUDI has rotating impactor plates that provide nearly uniform deposits over circular impaction areas. Polycarbonate-coated Nuclepore filters (0.4- $\mu \mathrm{m}$ pore size, with 47-mm Fomblin filters) were used, with a $1-\mu \mathrm{m}$ pore size after-filter and a flow rate of approximately $20 \mathrm{~L} \mathrm{~min}^{-1}$. During sampling, flow rates were controlled by a mass flow meter with a volume integrator.

During this campaign, the MOUDI operated on weekdays with an integration time of 10 hours during the day (diurnal samplings from 8:00 to 18:00 LT) and 14 hours at night (nocturnal samplings from 18:00 to 8:00 LT). Over the weekend, the integration time was 24 hours (from 8:00 to 8:00 LT). This resulted in six daytime samples, seven nighttime samples and two 24-hour samples. Mass analysis was carried out by gravimetry and the elemental concentrations were measured by Particle Induced X-ray Emission (PIXE). The PIXE analysis was performed on both samples and blanks at the Physics Institute of the University of São Paulo. The filters were irradiated with a $2.4-\mathrm{MeV}$ proton beam, at a typical current of $20 \mathrm{nA}$. The $\mathrm{X}$-ray spectra were accumulated for $600 \mathrm{~s}$, as recommended by Miranda et al. (2002). It was considered that all the sulfur presented in the sample, analyzed by PIXE, was ammonium sulfate. Ammonium sulfate showed simple unimodal size distribution during the day (with peak diameter of $0.38 \mu \mathrm{m}$ ) and bimodal size distribution at night $(0.38$ and $0.59 \mu \mathrm{m})$. The crustal material contribution was greater in larger cutoff diameter stages. Ynoue and Andrade (2004) showed that most of the fine mode mass in the MASP consisted of organic and black carbon and, in lesser quantities, ammonium sulfate. The three together appear to constitute the bulk of fine particulate matter in the region and that the dominant ions are ammonium, sulfate and nitrate. The authors showed that concentrations of crustal material had elevated concentrations at higher MOUDI stages, corresponding to the coarse fraction of the aerosol. The main crustal elements found were aluminum, silicon, titanium and iron. Based upon their results, the fine mode (smaller than $1 \mu \mathrm{m}$ ) receives a larger contribution from carbonaceous materials (organic carbon + black carbon) than from ammonium sulfate. The characteristics of urban aerosols in the São Paulo atmosphere are different from those in other urban areas because the primary source is mobile emission, which is also responsible for a significant portion of the particulate matter, specifically ultra-fine particles from light and mainly heavy duty-vehicle.

The CETESB monitoring stations house automatic gas samplers for $\mathrm{NO}, \mathrm{NO}_{2}, \mathrm{SO}_{2}, \mathrm{CO}$, total $\mathrm{HC}$, non-methane $\mathrm{HC}$ and $\mathrm{O}_{3}$, together with a beta gauge particulate monitor for PM10 (particulate matter with aerodynamic diameters less than $10 \mu \mathrm{m})$. The 29 automatic stations are distributed throughout MASP, as well as in Cubatão and other major cities within the state of São Paulo. There are 12 stations that measure $\mathrm{SO}_{2}$ and report hourly. No biogenic emissions are included.

\subsection{The scavenging modeling.}

The RAMS (version 4a) and scavenging model have been previously described elsewhere (Gonçalves et al., 2003 and Gonçalves et al., 2002). As a summary the numerical scavenging modeling was primarily divided into two main mechanisms: below-cloud and in-cloud scavenging processes. Below-cloud and in-cloud modeling were based on physical and mathematical assumptions, described in the previous works. The main modeling assumptions are: 
- The spatial structure of the scavenging modeling processes was based upon a vertical one-dimensional closed box: between the ground and cloud base for below-cloud modeling and between cloud base and cloud top for in-cloud modeling;

- The gas-scavenging modeling presents similar equations for both processes. Particulate matter (PM) scavenging modeling is also similar and includes nucleation processes;

- The in-cloud modeling was developed using the mesoscale numerical modeling RAMS. This was done in order to evaluate the following parameters:

a. The vertical profile of the cloud water content was used in order to obtain the cloud droplet spectra and to integrate the in-cloud scavenging processes along its vertical profile;

b. For low-resolution grids of RAMS, the vertical profile concentrations were obtained with a parameterization of sub-grid scale convective transport of gases and aerosol particles associated with deep and moist convection systems. Aerosol was considered without mass. The parameterization was based on the 'top-hat' method, has been coupled to the cumulus parameterization scheme of RAMS-CSU model;

- For below-cloud modeling, the existence of a uniform raindrop size distribution (DSD) was based on a given rainfall rate. No splitting, break-up events or other changes of the DSD took place during the event. Different function relations could express the DSD. The DSD used herein was divided into fifty classes of raindrop size, varying from $0.3 \mathrm{~mm}$ to $5.2 \mathrm{~mm}$ in diameter. The raindrop size distributions were also assumed to follow a Gamma function distribution as proposed in Gonçalves et al. (2000), relative to the measured rainfall rate for each event;

- The main chemical modeling reactions analyzed from gases absorption were also based on Gonçalves et al. (2000). $\mathrm{SO}_{2}$, was the gas and $\mathrm{SO}_{4}{ }^{=}$was the particulate matter, both used as input data (atmospheric concentrations). The prognostic variables were $\mathrm{SO}_{4}{ }^{=}$in rainwater.

- The particulate matter size distribution for all aerosol species is characterized by a lognormal function, according to Whitby (1978) and Jaenicke and Davies (1976) for rural distribution, urban and adjusted-urban distributions, within the 0.01 to $40 \mu \mathrm{m}$ radius and divided into 73 mass class sizes $\left(\mu \mathrm{g} \mathrm{m}^{-3}\right)$. Particle mass and number distributions are assumed to be temporally constant with respect to particulate aerodynamic diameter, or rather; hygroscopic growth is not considered (Figure 2). Particle density is assumed to be equal to $1 \mathrm{~g} \mathrm{~cm}^{-3}$. A measured aerosol spectra from a MOUDI collector is also used, herein referred to as the adjusted-urban spectra, presented in Table 1 (Ynoue and Andrade, 2004).

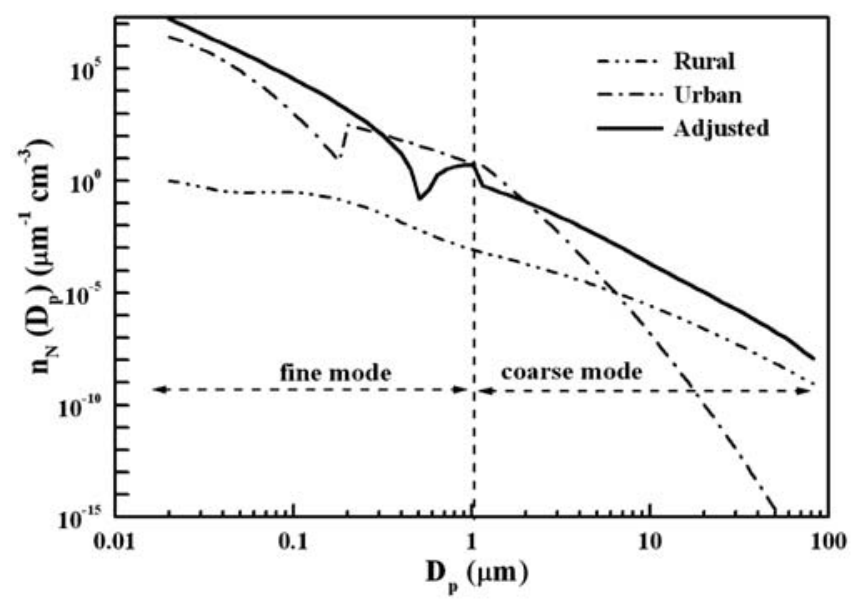

Figure 2 - Aerosol input spectra in number per diameter class. Rural and urban adapted from Whitby (1978) and urban adjusted for sulfate (extracted from local measurements).

Table 1 - Average chemical composition of aerosol fine mode particles (in $\mu \mathrm{g} / \mathrm{m}^{3}$ ) as a function of their size during (a) daytime and (b) nighttime, where AF means "after-filter".

\begin{tabular}{|c|c|c|c|c|c|}
\hline \multicolumn{6}{|c|}{ (a) daytime } \\
\hline $\begin{array}{c}D_{50} \\
(\mu \mathrm{m})\end{array}$ & $\mathrm{SO}_{4}=$ & $\mathrm{NH}_{4}^{+}$ & $\mathrm{NO}_{3}^{-}$ & BC & Mass \\
\hline $\mathrm{AF}$ & 0.85 & 0.76 & 0.20 & 2.5 & 10.2 \\
\hline 0.18 & 1.53 & 1.10 & 0.15 & 0.3 & 18.1 \\
\hline 0.32 & 1.18 & 0.85 & 0.12 & 0.2 & 14.4 \\
\hline 0.56 & 0.91 & 0.71 & 0.13 & 0.5 & 10.7 \\
\hline 1 & 0.72 & 0.36 & 0.31 & 0.3 & 11.8 \\
\hline 1.8 & 0.21 & 0.21 & 0.38 & 0.2 & 10.7 \\
\hline Total & 5.39 & 3.99 & 1.30 & 4.05 & 75.90 \\
\hline \multicolumn{6}{|c|}{ (b) nighttime } \\
\hline $\begin{array}{c}D_{50} \\
(\mu \mathrm{m})\end{array}$ & $\mathrm{SO}_{4}=$ & $\mathrm{NH}_{4}^{+}$ & $\mathrm{NO}_{3}^{-}$ & BC & Mass \\
\hline $\mathrm{AF}$ & 1.03 & 0.47 & 0.13 & 6.1 & 12.1 \\
\hline 0.18 & 1.68 & 0.97 & 0.08 & 0.4 & 17.3 \\
\hline 0.32 & 1.20 & 0.69 & 0.10 & 0.2 & 11.0 \\
\hline 0.56 & 1.49 & 0.79 & 0.15 & 0.6 & 10.4 \\
\hline 1 & 0.76 & 0.31 & 0.28 & 0.4 & 7.8 \\
\hline 1.8 & 0.16 & 0.03 & 0.39 & 0.2 & 7.5 \\
\hline Total & 6.32 & 3.27 & 1.14 & 8.03 & 66.06 \\
\hline
\end{tabular}

The main RAMS parameterization are:

- The homogeneous initialization uses the radiosonde data acquired at Congonhas Airport (usually at 09:00 LT), which is in the São Paulo city center, with or without NCEP/NCAR reanalysis. Three-dimensional nested grids are used. The coarse grid specification were assumed to be $20 \times 20 \mathrm{~km}$, 
the other two having $4 \mathrm{~km}$ and $1 \mathrm{~km}$ horizontal resolutions (see also Figure 1), respectively, with $\delta z$ of $100 \mathrm{~m}$, a 1.2 vertical grid stretch ratio and $500 \mathrm{~m}$ maximum $\delta$ for vertical stretch. Time steps were assumed to be $20 \mathrm{~s}$, with $2 \mathrm{~s}$ being the smallest;

\subsection{Statistics methods}

The following statistical tools are used in order to provide a comparison between modeled and observed data groups: correlation coefficient and root mean square error (RMSE). In this study, the variables behave as lognormal functions, therefore the Pearson correlation coefficient is calculated using these variables in the lognormal distribution.

In order to perform the modeling described above, case studies were selected from among rainfall events occurring on the university campus. The events of July 26, 1989, July 15, 2000 and July 23, 2000 were chosen because, for these events, complete data for the modeling analysis were available for the various scenarios (below-cloud and in-cloud scavenging using size distribution spectra from rural, urban and adjusted-urban areas). Two numerical modeling simulations (below-cloud scavenging or in-cloud scavenging, both using the various spectra distributions) were designed for the July 15, 2000 and July 23, 2000 events at both locations. Observed and modeled concentrations were compared.

\section{RESULTS AND DISCUSSIONS}

\subsection{Synoptic description of July 26, 1989, July 15, 2000 and July 23, 2000 rainfall events}

In the July 26, 1989 event, a frontal system arrived in the MASP at approximately 18:00 LT on July 25. This system

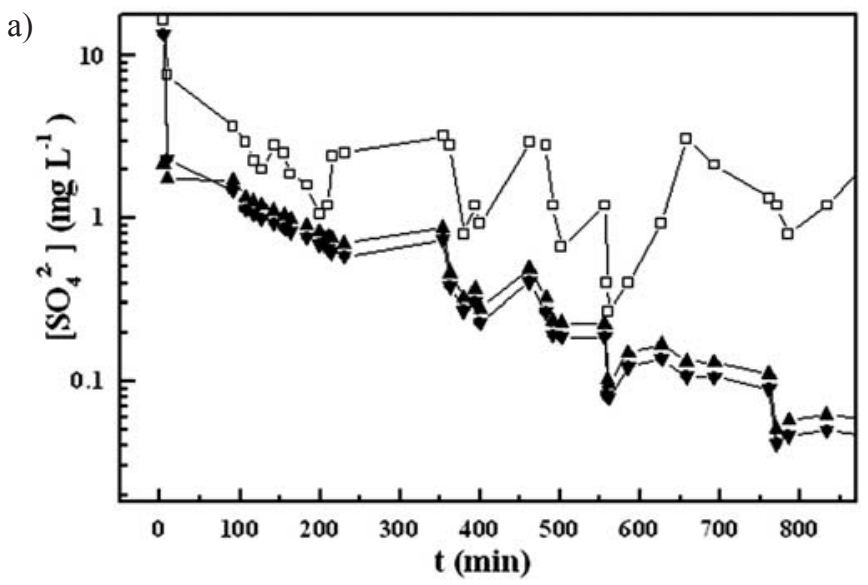

created $46.5 \mathrm{~mm}$ of precipitation from 3:25 LT to 20:00 LT. The July 15, 2000 event was characterized as stratiform and was caused by a cold front approaching the site at 16:40 LT and passing at 23:00 LT. The integrated precipitation totaled $15.7 \mathrm{~mm}$. The July, 23, 2000 event was also characterized as stratiform, remaining over the station from 5:00 LT to 23:00 LT and releasing $34.6 \mathrm{~mm}$ of total precipitation.

\subsection{Results of the modeling for the July 26, 1989, July 15, 2000 and July 23, 2000 rainfall events: PM spectra differences}

Figures 3 to 5 show the observed and modeled rainwater sulfate concentrations with the three spectra: urban, adjusted-urban and rural. Compared to the rural and adjusted-urban spectra, the urban spectrum exhibited different behavior. Rural and adjusted-urban spectra provided the highest early sulfate rainwater concentrations due to the fact that there was a greater amount of larger-diameter aerosol particles (and consequently more mass in the coarse fraction) than in the urban spectrum. The collision efficiency increases until it reaches near unity for aerosols larger than $2.5 \mu \mathrm{m}$. Consequently, the coarse fractions of both rural and adjusted-urban spectra are quickly removed, generating higher rainwater concentrations in the first samples (Figures 3 to 5). On the other side, in the urban spectra, the rainwater concentrations show a mild decrease and therefore do not show a statistically significant correlation coefficient with the observed curves, as it is described as it follows. Tables $2 \mathrm{a}$ and $2 \mathrm{~b}$ show those results. These results also emphasize that rural and urban-adjusted spectra generally have higher correlation coefficients and smaller RMSE values than urban spectrum. All results show a RMSE-to-observed values ratio lower than the observed data standard deviations, demonstrating the goodness of fitting.

b)

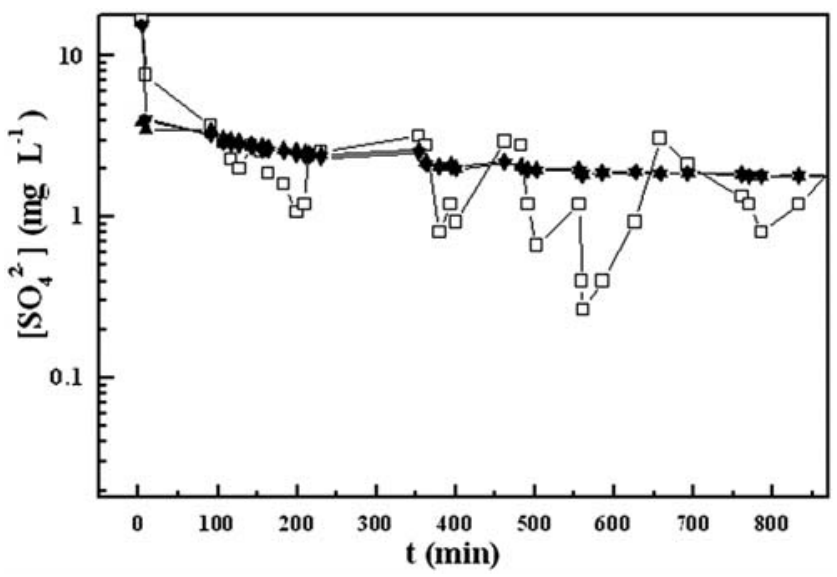

Figure 3 - Sulfate rainwater concentration $\left(\mathrm{mg} \mathrm{L}^{-1}\right)$ during July 26th 1989 rain event. Observed data $(\square)$ and modeled using rural ( $\square$ ), urban $(\mathbf{\Delta})$ and adjusted (-) aerosol spectra distribution: (a) below-cloud modeling; (b) below-cloud + in-cloud modeling.. 
a)

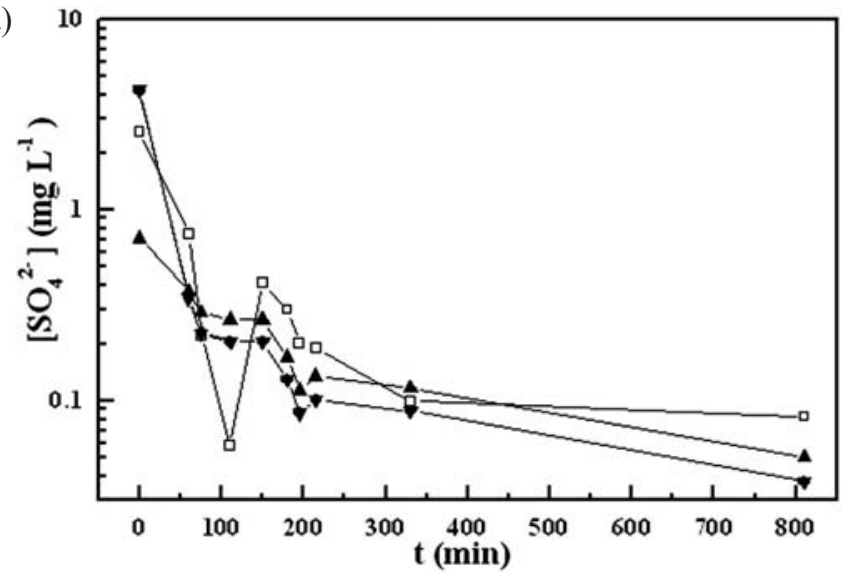

b)

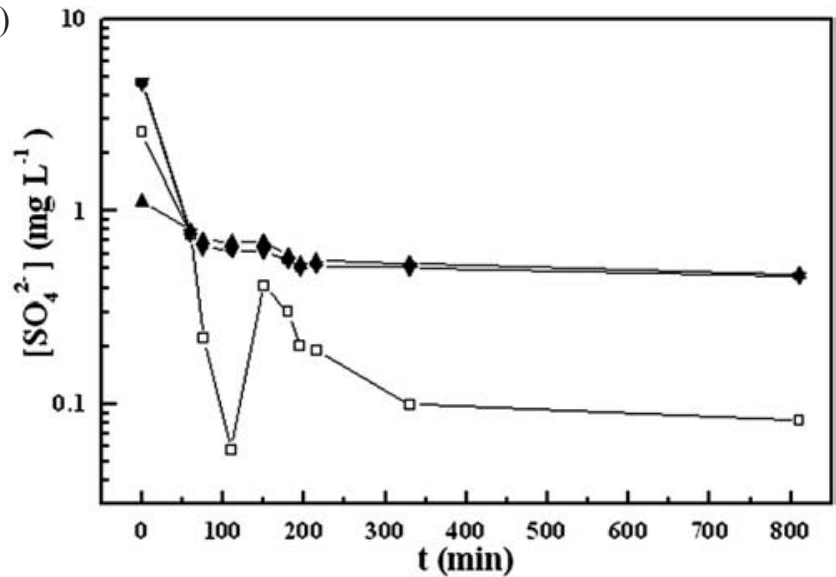

Figure 4 - Sulfate rainwater concentration $\left(\mathrm{mg} \mathrm{L}^{-1}\right)$ during July $15^{\text {th }} 2000$ rain event. Observed data $(\square)$ and modeled using rural ( $\left.\square\right)$, urban $(\mathbf{\Delta})$ and adjusted ( ) aerosol spectra distribution: (a) below-cloud modeling; (b) below-cloud + in-cloud modeling.

a)

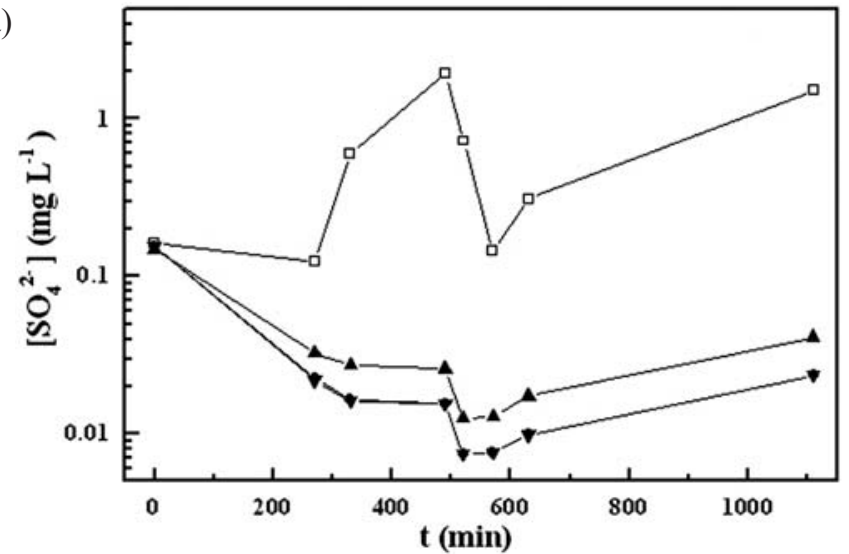

b)

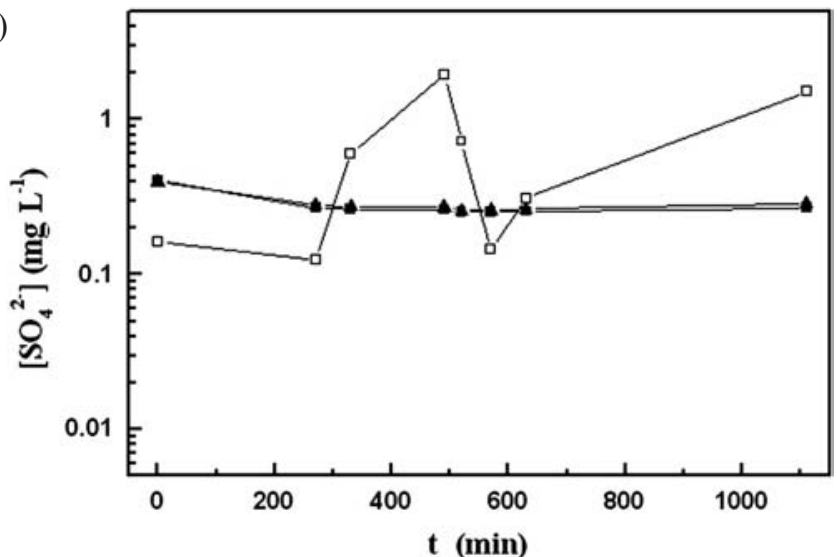

Figure 5 - Sulfate rainwater concentration $\left(\mathrm{mg} \mathrm{L}^{-1}\right)$ during July $23^{\text {th }} 2000$ rain event. Observed data $(\square)$ and modeled using rural ( $\left.\square\right)$, urban $(\mathbf{\Delta})$ and adjusted (-) aerosol spectra distribution: (a) below-cloud modeling; (b) below-cloud + in-cloud modeling.

From those Tables, the correlation coefficients are 0.71 for spectra from rural and adjusted-urban, respectively, versus 0.68 for the urban spectrum during the July 26, 1989 event (see also Figures $3 \mathrm{a}$ and $3 \mathrm{~b}$ ). The RMSE event averages were 0.47 for rural and adjusted-urban spectra, respectively, versus 1.48 for the urban spectrum during the same event. For the July 15, 2000 event, the rural and urban-adjusted spectra presented a coefficient correlation of 0.98 , whereas that of the urban spectrum was 0.92 . The RMSE for this event was approximately 0.43 for rural and urban-adjusted spectra and 0.37 for the urban spectrum. All these statistical results were heavily influenced by the values of the first samples for the modeled and observed data (Figures 3 to 5).

On the other hand, for July 23, 2000 event, there was no significant correlation among the spectra (Table 2a), despite of the fact that the RMSE values were lower, approximately 0.52 (on average) for all three spectra. An explanation for this result could be the wind direction. Unlike the two other case studies, the third one experienced an abrupt wind change, from northwest to south, after 16:00 LT (corresponding to after 300 minutes in Figures 5a 
Table 2a. Correlation coefficients between modeled and observed sulfate rainwater concentrations for different aerosol spectrum inputs in a lognormal distribution. Correlation coefficients $(\mathrm{p}<0.05)$.

\begin{tabular}{cccc}
\hline \multirow{2}{*}{ Spectrum } & \multicolumn{3}{c}{ Date } \\
\cline { 2 - 4 } & July 26, 1989 & July 15, 2000 & July 23, 2000 \\
\hline Rural & 0.71 & 0.98 & -0.33 \\
Urban & 0.68 & 0.92 & -0.30 \\
Adjusted-urban & 0.71 & 0.98 & -0.34 \\
\hline
\end{tabular}

Table 2b. Root mean square errors (RMSE) for modeled values divided by mean observed sulfate rainwater concentrations for different aerosol spectra and events, adding mean observed values and their respective standard deviations.

\begin{tabular}{cccccc}
\hline RMSE/Observed & $\begin{array}{c}\text { Rural } \\
\text { spectrum }\end{array}$ & $\begin{array}{c}\text { Urban } \\
\text { spectrum }\end{array}$ & $\begin{array}{c}\text { Adjusted } \\
\text { spectrum }\end{array}$ & $\begin{array}{c}\text { Mean } \\
\text { observed }\end{array}$ & $\begin{array}{c}\text { Standard } \\
\text { deviation }\end{array}$ \\
\hline July 26, 1989- a & 0.23 & 1.16 & 0.23 & 2.27 & \pm 2.68 \\
\hline July 26, 1989- b & 0.70 & 1.80 & 0.70 & 2.27 & \pm 2.68 \\
\hline July 15, 2000- a & 0.31 & 0.38 & 0.30 & 0.49 & \pm 0.76 \\
\hline July 15, 2000- b & 0.56 & 0.36 & 0.54 & 0.49 & \pm 0.76 \\
\hline July 23, 2000- a & 0.62 & 0.61 & 0.62 & 0.69 & \pm 0.68 \\
\hline July 23, 2000- b & 0.43 & 0.43 & 0.43 & 0.69 & \pm 0.68 \\
\hline & & & & $\begin{array}{l}\text { a, only below-cloud modeling } \\
\text { b, below-cloud + in-cloud modeling }\end{array}$
\end{tabular}

and $5 \mathrm{~b}$ ), during the event. This wind shift was confirmed with weather charts (Figure 6). It is of note that there is no advection within the scavenging model since it is a closed box.

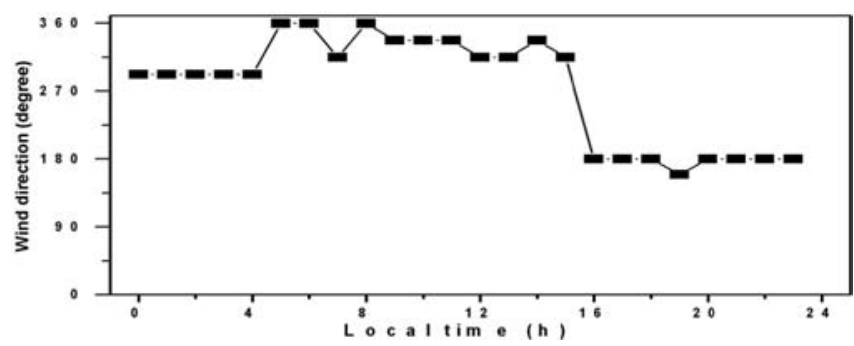

Figure 6 - Wind direction at USP during July $23^{\text {th }} 2000$.

These results, which seem to fit better with observed concentrations in the first two rainfall events, might be ascribed to local sources.

\subsection{Results of the modeling of the July 26, 1989, July 15, 2000 and July 23, 2000 events: in-cloud and below-cloud contributions}

Figures 3a, 4a and 5a show only below-cloud contributions with the overall decays, which are compared to the observed data curves. Upon including in-cloud contributions to the modeling (Figures $3 b, 4 b$ and $5 b$ ), the modeled values exceed the observed ones. The observed decays are more pronounced than are those in the below-cloud + in-cloud models, a fact that could be explained by the dominance of below-cloud scavenging (Naik et al., 1994), although quantitative data is not available.

Figures $5 \mathrm{a}$ and $5 \mathrm{~b}$ show that the behavior of the July 23 , 2000 event was different from that of the other events in that the expected decay is not seen. There was an intense increase after 300 minutes of rainfall. However, the direct high temporal resolution data do not indicate increased sulfate/sulfur dioxide in air, which would affect rainwater concentrations. This increase could, therefore, be due to the change in wind direction, as explained above.

\subsection{Results of the modeling of the July 15, 2000 and July 23, 2000 events: local differences}

Table 3 shows local average rainwater concentrations with the three modeled simulated concentrations, observed data and the PEFI/USP (both locations) ratios. In these three simulations, the in-cloud + below-cloud concentrations were also included. Despite the lack of agreement among observed and modeled values, the overall results show good agreement between the USP/PEFI ratios of modeled and observed values. Additionally, the $\mathrm{SO}_{2}$ input data was determinant to the modeled spatial variability which was found in both observed and modeled rainwater, through the USP/PEFI ratios, which emphasizes below-cloud scavenging. 
Table 3 - Results of the modeling for the July 15, 2000 and July 23, 2000 events, compared to the observed data for sulfate in rainwater $(\mathrm{mg} / \mathrm{L})$

\begin{tabular}{|c|c|c|c|c|c|c|}
\hline & \multicolumn{3}{|c|}{ July 15} & \multicolumn{3}{|c|}{ July 23} \\
\hline & USP & PEFI & ratio & USP & PEFI & ratio \\
\hline Observed & 0.49 & 1.29 & 2.63 & 0.69 & 0.87 & 1.26 \\
\hline \multicolumn{7}{|c|}{ Modeled in-cloud + below-cloud } \\
\hline urban & 2.08 & 6.19 & 2.98 & 0.49 & 0.58 & 1.17 \\
\hline adjusted-urban & 3.23 & 9.68 & 3.00 & 0.48 & 0.56 & 1.18 \\
\hline rural & 3.23 & 9.68 & 3.00 & 0.48 & 0.56 & 1.18 \\
\hline \multicolumn{7}{|c|}{ Modeled below-cloud only } \\
\hline urban & 1.07 & 3.18 & 2.98 & 0.07 & 0.09 & 1.18 \\
\hline adjusted-urban & 1.98 & 5.95 & 3.00 & 0.08 & 0.10 & 1.18 \\
\hline rural & 1.98 & 5.95 & 3.00 & 0.08 & 0.10 & 1.18 \\
\hline
\end{tabular}

From Table 3, using only below-cloud modeling, modeled values are closer to observed values than when below-cloud and in-cloud processes are considered together. However, in the July 15, 2000 event, as anticipated by Gonçalves et al. (2002), below cloud modeled values are twice as high as observed values in the urban spectrum and in-cloud + below cloud modeled, four times higher. With the two other spectra, the values are even higher than observed values. Therefore, the below-cloud modeling seems to estimate the observed values rather than the both scavenging processes together. As it was explained in Gonçalves et al. (2002), the results show the expectant overestimation of the observed values. Similar results were obtained in the simulations conducted during the July 1989 campaign.

It is not that the case in the July 23, 2000 event, modeled and observed concentrations did not differ considerably, probably due to the previously mentioned shift in wind direction, which might have led to an increase in the observed data.

Therefore, there are usually significant differences between modeled and observed which could mostly be due to the non advection terms.

In general, the below-cloud process seems to play the most important role in atmospheric scavenging in these case studies, where local sources were dominant in the wet deposition contamination. This dominance was due to the pattern of wet deposition rather than to the amount of contamination.

\section{CONCLUSIONS}

The primary finding of this study was that below-cloud scavenging dominates in winter stratiform events. We base this conclusion on the great spatial variability of the concentrations of compounds in rainwater and on the behavior of the rate of pollutant removal, as evidenced by the lower values seen in samples collected later in the event. The comparison between two different locations seems to support the idea that below-cloud scavenging dominates the stratiform event scenario. For example, atmospheric concentrations of $\mathrm{SO}_{2}$ also indicate a local influence, which plays a very important role in the water chemistry. Wind direction also plays an important role, as can be noted when there is an abrupt variation in wind direction. Modeling of scavenging processes compared favorably with the observed results, confirmed by the low RMSE values thereby demonstrating the dominance of below-cloud scavenging. The differences

The results indicate that the aerosol size distribution spectra play a major role in the removal process, which is clearly seen through the numerical modeling. Adjusted-urban (MASP) and rural spectra gave the best representation of the concentrations of the various compounds in rainwater, presenting smaller RMSE values than did the urban spectra. Our results also indicate a possible local influence due to the fact that both USP and PEFI are surrounded by natural aerosol sources, i.e. vegetation that matches the rural spectrum or adjusted-urban, within the urban area. The adjusted sulfate aerosol spectrum exhibits a mixture of rural and urban characteristics, though more similar to that of the rural spectrum. Those results also favor the improvement of the scavenging modeling which thereafter will use the aerosol spectra as in important input data.

\section{ACKNOWLEDGEMENTS}

We are grateful to Dr. Cristina Forti (INPE) for the rainwater chemical analysis, as well as to CETESB (São Paulo State Environmental Agency) for the gaseous concentration and FAPESP, for their financial support (Nr. 98/16297-0). 


\section{REFERENCES}

BAEZ, A.; BELMONT, P.R.; PADILLA, H., 1992. Variation of chemical composition of wet precipitation using a sequential sampling: urban-rural areas. Atmosfera, v. 6, p. 163-174.

CAUTENET, S., LEFEIVRE, B.: 1994. Contrasting behavior of gas and aerosol scavenging in convective rain: a numerical and experimental study in the African equatorial forest. Journal of Geophysical Research, v.99, p.13013-13024.

CETESB, 2003, Relatório de Qualidade do Ar no Estado de São Paulo - 2002, Secretaria do Meio Ambiente, Série Relatórios ISSN 0103-4103, São Paulo (www.cetesb.sp.gov.br).

COWLING E. B.: 1982. Acid precipitation in historical perspective. Environmental Science Technology 16(2), p. $110 \mathrm{~A}-123 \mathrm{~A}$.

DURANA, N., CASADO, H., EZCURRA, A., GARCIA, C., LACAUX, J.P., DINH, P.V.: 1992. Experimental study of the scavenging process by means of a sequential precipitation collector, preliminary results. Atmospheric Environment 26A(13), p. 2437-2443.

FLATAU, P.J.: 1989. The CSU RAMS Cloud Microphysical module: General Theory and Code Documentation. Colorado St. Univ. Dep. Atm. Sci. Fort Collins, CO 80523. Atmospheric Science, p.451.

FORNARO,A.: 1991. Chuva ácida em São Paulo: caracterização química de amostras integradas e seqüenciais de deposição úmida., Master Dissertation at Instituto de Química (Chemistry Institute), University of São Paulo.

FORNARO, A., GUTZ. I.G.R.: 2003. Wet deposition and related atmospheric chemistry in the São Paulo Metropolis, Brazil: Part 2. Contribution of formic and acetic acids. Atmospheric Environment v.37, p.117-128.

FORNARO, A., ISOLANI, P.C., GUTZ, I.G.R., 1993. Low-cost automated rain collector and its application to the study of wet-only deposition in São Paulo (Brazil). Atmospheric Environment v.27(B), 307-312.

FORTI, M.C., MOREIRA-NORDEMANN, L.M., ANDRADE, M.F.; ORSINI, C.Q.: 1990, Elements in the precipitation of S. Paulo City (Brazil). Atmospheric Environment v.24B, p. $355-360$.
GONÇALVES, F.L.T., MASSAMBANI O., BEHENG, K.D., SOLCI, ROCHA, V., M.C., SCHILLING, M.,VAUTZ, W., KLOCKOW, D.: 2000. Modelling and measurements of below scavenging processes in the highly industrialized region of Cubatão-Brazil. Atmospheric Environment v.34, p. 4113-4120.

GONÇALVES, F.L.T., MALHEIROS, A. R., FREITAS, R. S., ASSUNÇÃO, M. A. F., MASSAMBANI O.: 2002. In-cloud and below-cloud numerical simulation of scavenging processes at Serra do Mar region, SE Brazil. Atmospheric Environment, v.36, (33), p. 5245-5255.

GONÇALVES F.L.T., ANDRADE, M.F., FORTI, M.C., ASTOLFO, R., RAMOS, M.A., MASSAMBANI, O., MELFI, A.J.: 2003. Preliminary estimation of the rainfall chemical composition evaluated through the scavenging modeling for North-eastern Amazonian region (Amapá State, Brazil). Environmental Pollution v.121(1), p.63-73.

JAENICKE R., DAVIES, C.N.: 1976. The mathematical expression of the size distribution of atmospheric aerosols. Journal of Aerosol Science v.7, p. 255-259.

KLOCKOW, D., TARGA, H.J., VAUTZ, W.: 1996. Air pollution and vegetation damage in the Tropics- the Serra do Mar as an example: Final report 1990-1996. German/Brazilian Cooperation in Environmental Research and Technology, $150 \mathrm{p}$.

LEVINE, S.Z., SCHWARTZ, S. E.: 1982. In-cloud and below-cloud scavenging of nitric acid vapor. Atmospheric Environment v.6, p. 317-320.

LIM, B., JICKELLS, T.D., DAVIES, T.D.: 1991. Sequential sampling of particles, major ions and total trace metals in wet deposition. Atmospheric Environment v.25A(3-4), p. 745-762.

MINOURA, H., IWASAKA, Y.: 1996. Rapid change in nitrate and sulfate concentrations observed in early stage of precipitation and their deposition process. Journal Atmospheric Chemistry v.24, p. 39-55.

MIRANDA, R.M., ANDRADE, M.F., WOROBIEC, A., GRIEKEN, R.V.: 2002. Characterization of aerosol particles in the São Paulo Metropolitan Area. Atmospheric Environment v.36, p. 345-352. 
MOLINARI, J., 1985. A general-form of Kuo cumulus parameterization. Monthly Weather Review v.113, p.1411-1416.

NAIK, M.S; KHEMANI, L.T.; MOMIN, G.A.; RAO, P.S.P.; SAFAI, P.D.: 1994. Variation in the ionic composition in convective showers in Pune, India. Tellus, v.46B, p. 68-75.

PAIVA, R.P., PIRES, M.A.F., MUNITA, C.S., ANDRADE, M.F., GONÇALVES, F.L.T., MASSAMBANI, O.: 1997. A preliminary study of the anthropogenic contribution to São Paulo rainfall. Fresenius Environmental Bulletin v.6, p. 508-513.

PANDIS, S.N., SEINFELD, J.H., PILINIS, C.: 1990. Chemical composition differences among droplets of different sizes. Atmospheric Environment v.24A, p.1957-1969.

POISSANT, L., BÉRON, P.: 1992. Design and operation of an automatic sequential rainfall sampler. Water Research v.26(4), p. 547-551.
ROCHA, F.R, SILVA, J.A.F., LAGO, C.L, FORNARO, A., GUTZ. I.G.R.: 2003. Wet deposition and related atmospheric chemistry in the São Paulo Metropolis, Brazil: Part 1. Major inorganic ions in rainwater as evaluated by capillary electrophoresis with contactless conductivity detection, Atmospheric Environment v.37, p. 105-115.

SEINFELD, J.H., PANDIS, S.N.: 1998. Atmospheric Chemistry and Physics: from Air Pollution to Climate Change. John Wiley \& Sons, New York, 1326 p.

WHITBY, K.T.: 1978. The physical characteristics of the sulfur aerosols. Atmospheric Environment v.12, p.135-159.

YNOUE, R.Y., ANDRADE, M.F.: 2004. Size resolved mass balance of aerosol particles over the Metropolitan Region of São Paulo, Brazil. Journal of Aerosol Science and Technology, v. 38, p. 52-62, 2004. 